\title{
Femurfraktur og kjeveleddsdestruksjon etter bruk av bisfosfonater
}

\author{
Bisfosfonater er av de vanligste legemidlene til behandling av osteoporose. De siste årene er det rapportert \\ om bivirkninger etter langtidsbehandling. Vi beskriver her en pasient som etter langtidsbehandling med alen- \\ dronsyre fikk atypisk femurfraktur bilateralt og kjeveleddsdestruksjon. Så vidt vi vet er dette ikke beskrevet \\ tidligere hos postmenopausale kvinner etter langvarig bisfosfonatbruk.
}

En kvinne i 70-årene pådro seg periprotetisk spontanfraktur i begge femurdiafysene fem år og $11 / 2$ år etter artroplastikk for hofteartrose. Forut for frakturene hadde hun hatt lårsmerter i noen måneder. Røntgenundersøkelse ga ingen holdepunkter for direkte proteserelatert årsak. På høyre side forelå en dislokert fraktur og på venstre side en inkomplett fraktur, begge med karakteristika som ved stressfraktur.

Det fremgikk at pasienten de siste 14 årene hadde fătt osteoporoseprofylakse i form av alendronsyre (Fosamax) $10 \mathrm{mg}$ daglig uten behandlingspauser.

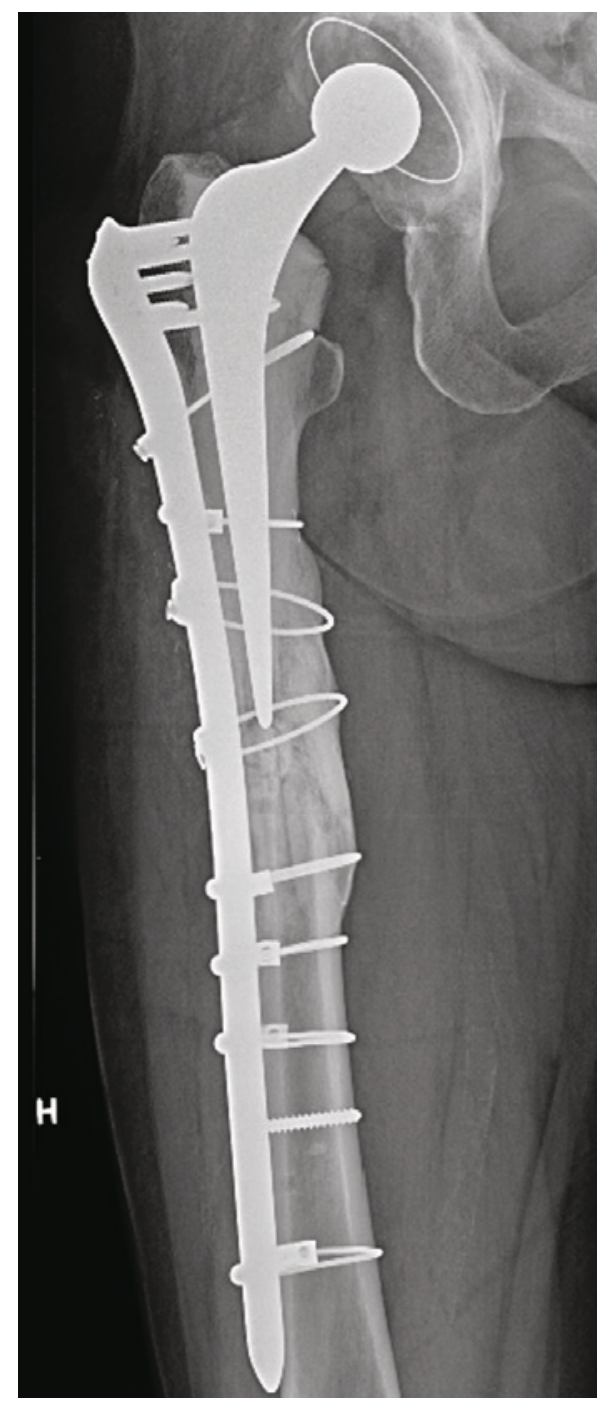

Figur 1 Konsolidert fraktur i høyre femur, 31 måneder etter skaden
Begge frakturene ble fiksert med vinkelstabil plate (LCP). Forsinket tilheling krevde først revisjon av osteosyntesen på høyre femur, supplert av autologe beintransplantat (chips) fra crista iliaca og strukturelle, kortikale transplantat fra fibula. Alendronsyre ble seponert. 31 måneder etter det første inngrepet var frakturen konsolidert, med inkorporerte strukturelle transplantat (fig 1). På venstre side sviktet osteosyntesen, med økende aksefeil i frakturen. Først etter to kirurgiske revisjoner, siste gang med tillegg av strukturelle allograft, helet frakturen. 22 måneder etter første inngrep var frakturen konsolidert.

Pasienten har i lange perioder sittet i rullestol. I dag, ca. fem år etter første frakturoperasjon, kan hun stort sett bevege seg uten hjelpemidler innendørs, men hun er avhengig av krykker når hun går utendørs.

I tillegg har pasienten fått tiltakende kjeveproblem i form av bittforandring med tilbakefall av underkjeven og utvikling av åpent bitt $\mathrm{i}$ fronten og premolarregionene. Ett år etter seponering av alendronsyre var det bittåpning med avstand mellom incisalkantene på 11 og 41 på $2 \mathrm{~mm}$. 2,5 år senere hadde denne økt til $5 \mathrm{~mm}$. Røntgenundersøkelse, ortopantomogram (OPG) av mandibula og computertomografi (CT) av kjeveledd viste progredierende degenerative forandringer $\mathrm{i}$ begge kjeveledd med avflatning av processus condylaris og defekter på leddflaten, mest uttalt på venstre side. 3,5 år etter seponering av alendronsyre var processus condylaris på venstre side nærmest borte. Pasienten har nå kontakt bare på de bakerste molarene på hver side. Dette medfører betydelige spiseog talevansker. Hun har nå problemer med å bite av en vanlig brødskive og har fått en lespende tale (fig 2).

\section{Alvorlige bivirkninger}

Det siste tiåret har mange sett på en mulig sammenheng mellom atypiske frakturer i femurskaftet og bruk av alendronsyre og andre bisfosfonater. Feldstein (1) mener at det er en usikker eller liten sammenheng, med en relativ risiko på 2 , mens Schilcher finner en relativ risiko på 47 (2).

Ut ifra kunnskap om biologiske endringer $\mathrm{i}$ beinvev under påvirkning av bisfosfonater, bl.a. med nedsatt osteoklastaktivitet og dermed nedsatt remodellering, kan man regne med at frakturene oppstår som følge av at beinets kontinuerlige reparasjonsprosess er mangelfull. Mikrofissurer danner etter hvert større fissurer og ender som fraktur, under betegnelsen atypisk fraktur. Selv om de radiografiske kriteriene for atypisk fraktur og stressfraktur er like, er de patogenetisk helt forskjellige. Stressfrakturer oppstår ved sterk belastning av friske knokler over tid, slik man ser hos idrettsutøvere og militært personale.

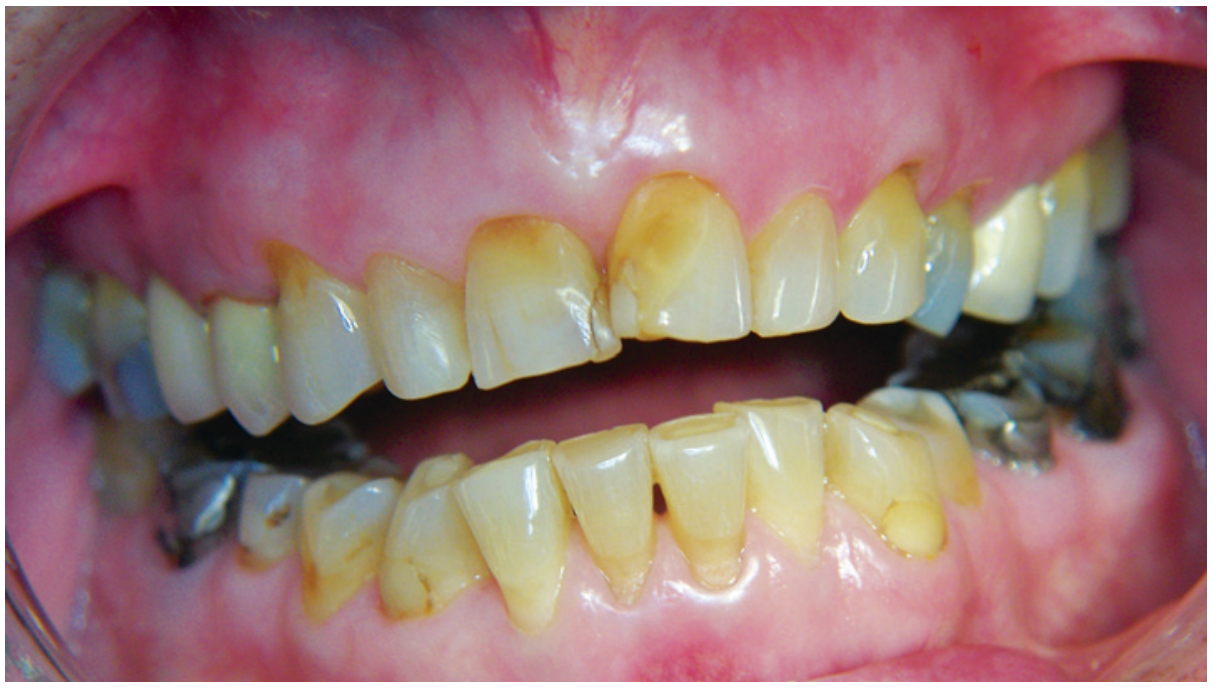

Figur 2 3,5 år etter seponering av alendronsyre. Pasienten har nå kontakt bare på de bakerste molarene. Bittåpning på 5 mm mellom incisalkantene på 11 og 41 
Det er bred enighet om at periprotetiske femurfrakturer etter hofteartroplastikk helst behandles med intern fiksasjon (3). Det svenske hofteregisteret rapporterer $34 \%$ svikt av osteosyntesene ved denne frakturtypen. Når frakturene dessuten er atypiske, vil komplikasjonsraten kunne tenkes å bli enda høyere. Atypisk femurfraktur som oppstår periprotetisk, er ikke omtalt tidligere, så vidt vi kan se. Det gir ytterligere økt usikkerhet rundt prognosevurdering og behandlingsvalg.

Spesielt designede plater som gir en dynamisk kompresjon og som tillater at skruene settes vinkelstabilt og med ulik vinkel på platen, sikrer stabiliteten i konstruksjonen, samtidig som implantatet ikke kommer i konflikt med protesekomponenter eller sementmantel. Alternativt kan kabelcerclage erstatte en eller flere skruer. I løpet av det siste tiåret er det også utviklet platesystem som gjør det mulig å koble små endeplater til hovedplaten, proksimalt og/eller distalt, for å dekke hele femurs lengde. Adekvat fiksasjon av frakturen kan oppnås med bruk av disse implantatene, kombinert med strukturelle, kortikale transplantat formet som plater, og dessuten bruk av spongiøse beintransplantat (chips).

Denne behandlingsstrategien ble først implementert i sin helhet ved de kirurgiske revisjonene hos vår pasient og førte til at frakturene omsider helet.

Osteonekrose i kjevene hos pasienter som bruker bisfosfonater ble første gang beskrevet i $2003(4,5)$. Det synes å være en klar sammenheng mellom langvarig bruk av bisfosfonater og kjeveosteonekrose, særlig hos kreftpasienter som har fått bisfosfonater ved infusjon. Bevisene for en slik sammenheng vanskeliggjøres ved at disse pasientene vanligvis har en annen komorbiditet og tar en rekke andre medikamenter som analgetika, steroider og cytostatika. Men det er også rapportert om mange tilfeller med kjeveosteonekrose hos osteoporosepasienter som kun har stått på perorale bisfosfonater (6). Vi har ikke funnet litteratur som omhandler kjeveleddsdestruksjon og langvarig bruk av bisfosfonater. Ettersom bisfosfonatene griper inn i beinets utskiftningsmekanismer bl.a. ved å hemme osteoklastfunksjonen og angio- neogenesen (7) er en slik sammenheng ikke usannsynlig.

Behandling av bittproblemene hos vår pasient synes å være en stor utfordring, idet bittåpningen er for stor til å la seg korrigere ved bittsliping og protetisk kroneterapi. Ettersom dette synes å være en pågående

\section{«Når det forskrives medikamenter som har innvirkning på fundamentale bio- logiske mekanismer, må pasienten følges opp over tid»}

destruksjonsprosess, er dessuten residiv overveiende sannsynlig etter en slik behandling. Den mest aktuelle behandlingen ville trolig være kirurgisk rekonstruksjon av kjeveleddene med ribbeintransplantat, ev. innsettelse av totalproteser i kjeveledd.

Degenerative kjeveleddslidelser med bittforandringer som beskrevet hos vår pasient, er meget sjeldne hos ellers friske pasienter. Pasienten har ikke vært utsatt for skade eller fått medisinering som kunne tenkes å ha patogenetisk betydning, f.eks. kortikosteroider, annen hormonbehandling, strålebehandling eller cytostatika. Vi anser derfor den langvarige medikasjonen med bisfosfonater som en svært sannsynlig årsak til kjeve- og femurproblemene.

Advarsler om bivirkninger ved bruk av bisfosfonater i form av kjeveosteonekrose og atypiske femurfrakturer ble tatt med i Felleskatalogen først $\mathrm{i}$ henholdsvis 2008og 2010-utgaven. Vår pasient fikk ingen orientering om disse sjeldne, men meget alvorlige tilstandene.

Denne sykehistorien er et varsku og en påminnelse om at når det forskrives medikamenter som har innvirkning på fundamentale biologiske mekanismer, må pasienten følges opp over tid. Det er ikke nok å reiterere resepter.
Pasienten har gitt samtykke til at artikkelen blir publisert.

\section{Knut Skoglund}

knut.ret.ort@gmail.com

Olav Hjortdal

Knut Skoglund (f.1939) er spesialist i generell kirurgi og i ortopedisk kirurgi og er pensjonert overlege ved Ortopedisk avdeling, Sykehuset Innlandet, Lillehammer.

Forfatter har fylt ut ICMJE-skjemaet og oppgir ingen interessekonflikter.

Olav Hjortdal (f. 1929) er cand.odont., lic.odont., spesialist i oral kirurgi og oral medisin og pensjonert overtannlege ved Oralkirurgisk avdeling, Sykehuset Innlandet, Lillehammer. Forfatter har fylt ut ICMJE-skjemaet og oppgir ingen interessekonflikter.

Litteratur

1. Feldstein AC, Black D, Perrin N et al. Incidence and demography of femur fractures with and without atypical features. J Bone Miner Res 2012; 27 . 977-86.

2. Schilcher J, Michaëlsson K, Aspenberg P. Bisphosphonate use and atypical fractures of the femoral shaft. N Engl J Med 2011; 364: 1728-37.

3. Buttaro MA, Farfalli G, Paredes Núñez M et al. Locking compression plate fixation of Vancouver type-B1 periprosthetic femoral fractures. J Bone Joint Surg Am 2007; 89: 1964-9.

4. Marx RE. Pamidronate (Aredia) and zoledronate (Zometa) induced avascular necrosis of the jaws: a growing epidemic. J Oral Maxillofac Surg 2003; 61: 1115-7.

5. Løkken P, Skjelbred A, Skoglund A. Tannbehand ling av pasienter som medisineres med bisfosfonater. Nor Tannlegeforen Tid 2007; 117: 588-94

6. Toft Grønvold P. Nordal B. Bisfosfonatindusert osteonekrose i kjevene. Prosjektoppgave. Oslo: Det odontologiske fakultet, Universitetet i Oslo, 2007: 46

7. Carter G, Goss AN, Doecke C. Bisphosphonates and avascular necrosis of the jaw: a possible association. Med J Aust 2005; 182: 413-5.

Mottatt 8.9. 2014 og godkjent 27.10. 2014. Redaktør: Erlend Hem.

Publisert først på nett.

Engelsk oversettelse på www.tidsskriftet.no 